\title{
Correction to: The Role of Psychological Capital in Academic Adjustment Among University Students
}

\author{
Batel Hazan Liran ${ }^{1} \cdot$ Paul Miller ${ }^{1}$
}

Published online: 24 December 2019

(c) Springer Nature B.V. 2019

\section{Correction to: J Happiness Stud (2019) 20:51-65 https://doi.org/10.1007/s10902-017-9933-3}

In the original publication, Appendix 2: Psychological Capital Questionnaire (PCQ) was included by the authors without obtaining permission to reproduce the Psychological Capital Questionnaire (PCQ). Appendix 2 is removed from the article. The original article has been corrected.

Publisher's Note Springer Nature remains neutral with regard to jurisdictional claims in published maps and institutional affiliations.

The original article can be found online at https://doi.org/10.1007/s10902-017-9933-3.

Batel Hazan Liran

batelliran@gmail.com

1 University of Haifa, 31905 Haifa, Israel 